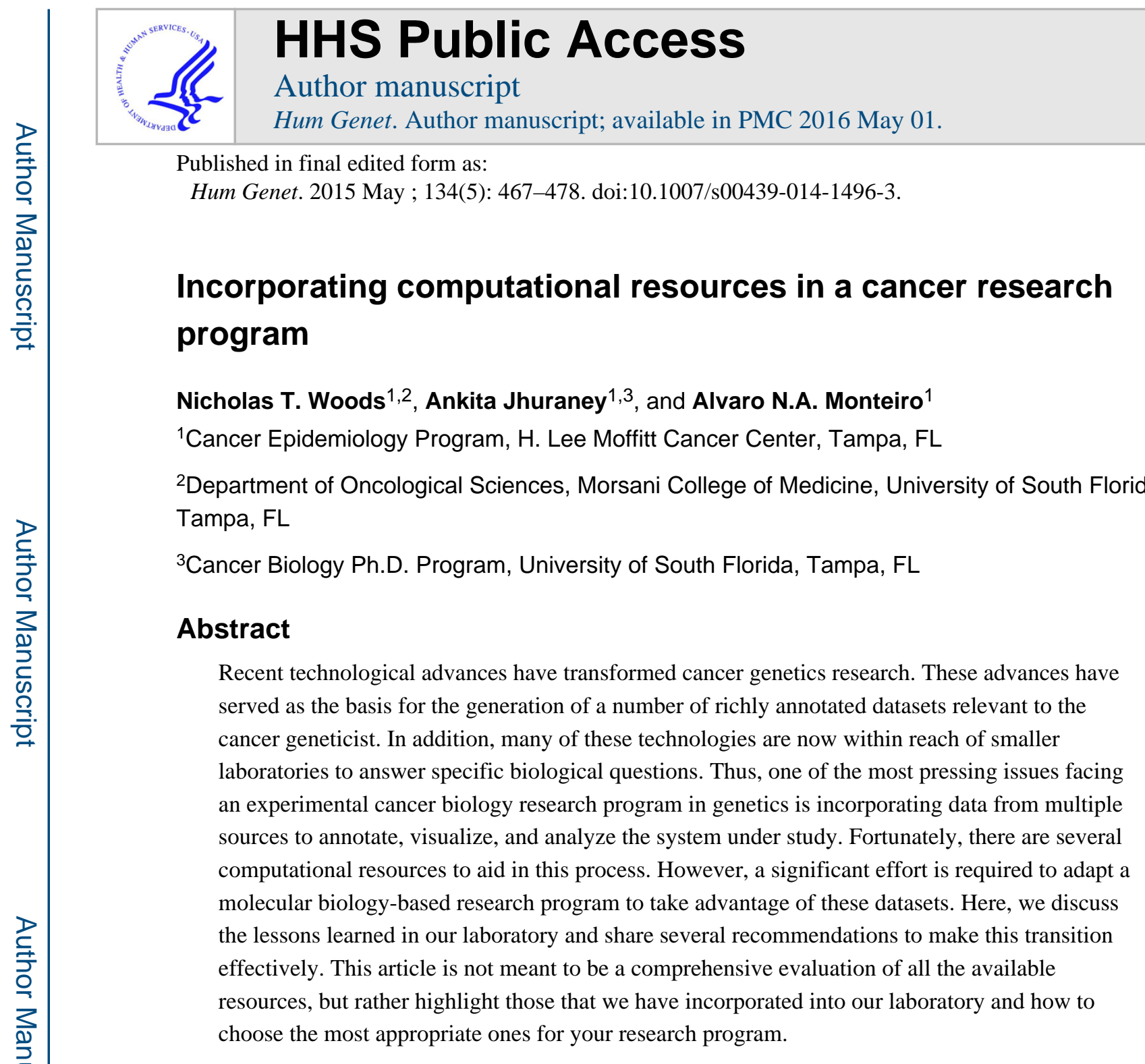

Keywords

Bioinformatics; computational tools; cancer genetics; methods

\title{
Introduction
}

Cancer research programs based on molecular biology, biochemistry and genetics have been traditionally reductionist in nature (Weinberg 2014). This highly successful framework was responsible for many advances seen in biology during the last several decades (Judson 1996). Lately, recent progress in high-throughput technologies such as microarray-based expression profiling (DeRisi et al. 1996; Schena et al. 1995), next-generation sequencing (Metzker 2010; Ronaghi 2001), and large scale genotyping (Hirschhorn and Daly 2005) have transformed cancer research in general and cancer genetics in particular. Through large consortia and initiatives these technologies were also the basis for a series of publically

Correspondence should be addressed to: Alvaro N. Monteiro, H. Lee Moffitt Cancer Center \& Research Institute, 12902 Magnolia Drive, Tampa, FL 33612, USA., Phone: 1-813-7456321, Fax: 1-813-9036847, alvaro.monteiro@ moffitt.org. 
available datasets relevant for cancer genetics such as ENCODE (Encyclopedia of DNA Elements; https://www.genome.gov/encode/), FANTOM (Functional Annotation of the Mammalian Genome; http://fantom.gsc.riken.jp/), TCGA (The Cancer Genome Atlas; http:// cancergenome.nih.gov/), ICGC (The International Cancer Genomics Consortium; https:// www.icgc.org/), and 1000 Genomes Project (http://www.1000genomes.org/). Effectively, the data generated by these technologies have transformed the field from a data poor to a data rich environment. As unique research opportunities arise in this data rich environment so do challenges to parse, integrate, and analyze data to annotate the underlying biological processes. Here, we report our experience in making this transition and provide specific examples and suggestions that can be applied so that a laboratory can explore these new research avenues.

We recognize three interconnected areas that have specific challenges: a) data generation, quality control, and data integrity; b) data analysis; c) data sharing and visualization (Figure 1). Over the past ten years we have tested different solutions applicable to the areas described above and chose a basic set of tools and procedures to be used in the laboratory. Our laboratory focuses on functional annotation of rare (Iversen et al. 2011; Karchin et al. 2007; Lee et al. 2010; Mirkovic et al. 2004) and common genetic variants (Bojesen et al. 2013; Monteiro and Freedman 2013; Pharoah et al. 2013) associated with cancer predisposition and their implication to signal transduction (Gerloff et al. 2012; Woods et al. 2012). Here, we discuss the lessons learned during this process. It is expected that each laboratory will have different needs and skill sets, so our guidance here is aimed at explaining the general framework on how to go about identifying the best tools for a specific laboratory and integrating them in your research workflow.

Paradoxically, while biology continues to become more computationally intensive, undergraduate and graduate biology curricula neither provide training on practical computational skills nor do they lay down a quantitative foundation for the statistical analysis of large datasets with multiple hypotheses testing. However, these are essential skills in today's research environment in cancer genetics and genomics and investing a small portion of time to acquire these skills will have significant scientific returns.

\section{Everyday Practice}

Although not every laboratory will re-tool to generate large data sets using high throughput methods, it is expected that in general most will be dealing with comparatively larger datasets (e.g. a handful of mutants versus several hundred mutants; one or two cell lines versus a panel of tens of cell lines, etc.) and should be aware of common pitfalls.

\section{Batch effects}

Not normally encountered in small-scale molecular biology experiments, batch effects are the systematic error introduced when a large (or sequentially collected) number of samples are processed in different batches. This is a common issue in microarray data where numerous samples have been collected and run by different labs and a joint analysis is attempted (Benito et al. 2004). The variability in microarray results is impacted by nonbiological factors, such as reagents from different lots, setup by different lab workers, and 
even changes in ozone (Fare et al. 2003; Lander 1999), which can be corrected using several algorithms (Chen et al. 2011). ComBat is one particular program that outperformed several others in a number of metrics in reducing batch effects (Chen et al. 2011; Johnson et al. 2007). However, batch effects can affect the analysis of any experiment collected in different batches. Statistical collaborators can develop algorithms to reduce the batch effects and should be involved in the project from initial design through analysis. However, it is always preferable to identify and resolve (or mitigate) technical issues that lead to batch effects than to correct or adjust for it.

\section{Record keeping and data integrity}

Most molecular biology labs continue to record their experiments in traditional paper-based lab notebooks with stapled, taped, or glued pictures and x-ray films. But high throughput experiments generate larger data sets often as output into a specific file format (fastq files for primary sequence data; BAM files for secondary sequence data and genomic coordinates; BCL files for base calling; VCF files for variant calling, etc.), or as data spreadsheets that facilitate analysis and generation of preliminary data displays. These are typically computer files stored separately from the lab notebooks and are seldom systematically referenced to other notes relating to that project. Use of these spreadsheets creates important challenges including the proliferation of different versions of the same files and data corruption during manipulation or merging of datasets. These problems can lead to delays of weeks or months and may lead to erroneous data interpretation and publication.

We suggest a simple system in which the file that contains the original raw data set (e.g. genotypes, luciferase assays, variant annotation, binding data, etc.) be stored in a shared drive as a frozen or locked copy. A copy available for editing and further data cleaning and analysis should be then made available to lab members. The final file used for analysis in a publication should also be locked and stored separately. They should also be deposited in a publically available database or published as supplementary data. If you want to promote further use of the datasets generated by your lab consider having the supplementary data in a machine extractable format instead of pdf files.

While most bench scientists are accustomed to documenting everything they do at the bench in their lab notebooks, it is not uncommon to fail to do so when they are working with a dataset. We recommend a readme file (attached to the data files) that documents the steps and procedures used to perform quality control, data cleaning, and analyses. Having a standardized way to name the files is extremely helpful and can include a descriptive title, the name of the person who generated/analyzed the data, the date and version, and which larger project it is part of (i.e.OVCa_WOODS_O3022014_V2_GWAS.txt).

Digital lab notebook tools such as Labguru (www.labguru.com) and Lab Archives (www.labarchives.com) provide a searchable platform to store and link programming files with output. Cloud-based services ensure user access to files and data even when away from the lab and easy file sharing between principal investigator and lab personnel. The downsides of these services are cost, storage limits, and issues with protection of patient health information. The goal should be to bring the lab data repository and organizational 
tools up to date to meet the growing reliance on digital information while maintaining the data on secure platforms to protect patient information according to the guidelines set forth by the US Health Insurance Portability and Accountability Act (http://www.hhs.gov/ocr/ hipaa).

The beginning of a project is an excellent time to start thinking about how the data will be reported. For the accurate and reliable interpretation of results and to ensure other researchers will be able to utilize the data, it is essential to report the data in a standardized manner. Given the diversity of biological data, it is no surprise that there are many different consortia and projects devoted to standardizing data reporting in biological research (Table 1). Failures in accurate reporting of minimal information about microarray experiments (MIAME) were found to greatly impair the reproducibility of microarray studies published in Nature Genetics from 2005 to 2006 (Ioannidis et al. 2009).

The key is to define a set of minimal procedures that can be accepted and implemented on a daily basis by every member of the laboratory. Procedures that are cumbersome or timeconsuming tend not to be embraced by lab members working at the bench. A good place to start is with a lab member that has just started a project and who will be more receptive to changing her record keeping procedures. An imperfect set of rules that works and is consistently applied is better than an ideal set that is never implemented.

\section{Basic programming, languages, and tools}

Many systems biology research projects in cancer aim to understand the information flow through biological networks to identify key genes or proteins relevant to the etiology of cancer or response to therapeutic agents. The datasets used to determine these relationships are at the discretion of the scientist and therefore tend to fall within his area of expertise. When making the decision to pursue systems level projects, many biologists abruptly encounter the barrier of manipulating large datasets, which requires a basic understanding of computational methods to handle these files.

Fortunately, there has been a significant expansion in the available number of computational resources. There are usually several different programs designed to handle the same type of analysis but they have seldom been benchmarked or compared. Thus, choosing which resource to utilize for each project can be overwhelming. In-depth review of the literature describing the programs usually requires an understanding of basic computation principles and complex statistical concepts. However, for biologists seeking to expand their research programs to include computational analyses there are many available resources to handle data collection and organization through the analysis pipeline and finally storage. For the cancer biologist interested in incorporating computational resources in their research program, knowledge of basic programing, gene/protein annotation, visualization software, and data analysis greatly aid in the process.

Once a biologist embarks on large-scale "omics" based research, one of the first challenges is organizing the data in a standard format and developing a workflow for specific projects. Basic programming or scripting is an extremely useful resource to handle these issues. Most data files can be parsed quickly and easily with just a few lines of code. Basic programming 
and text handling is useful for organizing data into acceptable formats and extracting data from files in a standard format.

When starting to write scripts it is important to note that these are generally not created at the command line or in a basic text editor such as notepad. Text editors that recognize and can help debug scripts, such as Komodo IDE (http://komodoide.com/features/), Emacs (http://www.gnu.org/software/emacs/), and BBEdit (http://www.barebones.com/products/ bbedit/) are some recommended editors to write scripts. For those interested in this software but do not need the advanced features, pared down free versions of BBEdit and Komodo IDE can be found in TextWrangler and Komodo Edit, respectively.

There are several programming languages available, and devoting time to learning any one of them takes a considerable investment. Prominent open-source programming languages commonly used in the life sciences are Perl (http://www.perl.org/), Python (https:// www.python.org/), and Java (http://www.java.com/en/). Several of our own laboratory projects have required the use of scripting to complete. In our case, two users had to learn a new programming language. User 1 was not familiar scripting, while the User 2 was more advanced and already knew Java and C. User 2 chose Perl, and with little effort was able to learn it very quickly. User 1 was interested mainly in parsing large data sets and was given the choice between Perl and Python. User 1 eventually chose Python but this was based on a personal choice rather than on programming capabilities. In our experience, learning the first language was the most difficult part of the process. Picking up other languages is generally easier because the user is able to leverage basic concepts of interacting with the computer and reading and writing in an alternative syntax. It should be anticipated that considerable effort is required to become proficient in any programming language.

Python is increasingly popular because of its simple syntax, making it easier to read and learn but still providing a powerful platform for program development. The reason Python is an easily readable language is that it often uses keywords rather than punctuation. An excellent introduction to Python programming for biologists has been developed by Haddock and Dunn, which can also serve as the text for teaching introductory bioinformatics courses to biology undergraduate or graduate students (Haddock and Dunn 2011). Perl is another commonly used scripting language used by beginners and advanced users alike and the Beginning Perl for Bioinformatics by James Tisdall (1st edition, 2001) is a good resource to start learning the language.

Aside from language specific information, essential skills for any beginner programmer include understanding regular expressions, using the shell to handle text and script and data management systems such as relational databases (e.g. MySQL). Although many in-depth technically driven manuals can be found on each of these subjects, biologists will likely be less intimidated by the teaching examples provided by Haddock and Dunn which describes commonly encountered biological data analysis problems that can be handled with simple programming code. Osborne et al. also provide a jargon-free guide for scientific researchers to developing and using software for research purposes (Osborne et al. 2014). As the language is mastered, researchers can continue to expand the basic concepts to tackle more complex data analyses and develop additional software. 
There are several excellent resources devoted to developing useful software for the analysis of biological data, such as Bioconductor (http://www.bioconductor.org/), BioPerl (http:// www.bioperl.org/wiki/Main_Page), and Biopython (http://biopython.org/wiki/Main_Page). The Bioconductor project is an initiative designed to promote the development of software tools that can be used for the analysis of biological data with an emphasis on those generated by microarrays or high-throughput genomics. However, useful modules are also available for analysis of other datasets, such as those generated by mass spectrometry. Bioconductor provides a number of well-annotated tools with task-oriented descriptions of functionality allowing a quick set up to start using the modules.

The overall goal of BioPerl and The Biopython Project is to produce code that is useful in the study of biology. These projects have numerous core modules and offer users a wellannotated description for the programs (Stajich et al. 2002). This repository of programs is especially useful for analysis of sequence data from online databases and includes modules to parse experimental files in numerous formats (e.g. FASTA, GenBank, ClustalW, and PubMed) and query online databases (e.g. NCBI's Entrez and Swiss-Prot) besides providing tools for routine operations on DNA or protein sequences (e.g. transcription, translation, and motif analysis). Many of the available modules are also designed to annotate and visualize sequence elements, These features streamline large-scale data extraction and analysis of sequences and allow users to compare sequence alignments, create sequence motifs and position-weight matrices. The functionality of these projects also extends into the fields of proteomics and structural biology. Both BioPerl and Biopython provide software for the interrogation of protein structure including working with crystal structure atomic data through the Bio.PDB module.

Since the functionalities of both BioPerl and BioPython are very similar in nature, the user may want to consider factors such as speed of the program for their specific application. Python is faster at global alignments and Neighbor-Joining, but slower in BLAST parsing when compared to Perl (Fourment and Gillings 2008). Overall, C, C++, and Java have better speed performance than Python and Perl for the same operations. The issue of speed does not considerably affect small-scale projects, but users who wish to do millions of operations at a time should consider speed as fractions of a second could cost days or weeks of analysis time for larger projects.

\section{Visualization tools}

Depicting data generated by large-scale data analyses presents unique challenges. With so many data points, how do we create figures that convey the scientifically significant aspects of a study in a manner that can be interpreted by scientists from different backgrounds? Visualization tools can be used not only as explanatory graphs (which convey the results in a graphical format) but also as exploratory and interactive (which allows for pattern recognition and integrating through multiple scales). For suggestions on data visualization we recommend Edward Tufte's books on visual displays (Tufte 1997, 2001).

Heat maps provide intuitive visualizations of relations between two data points and are excellent for depicting microarray results. However, how do we describe more than one 
attribute at a time? Several programs and platforms are available to aide researchers in this endeavor. The UCSC Genome Browser (http://genome.ucsc.edu/) and Circos (http:// circos.ca/), Integrated Genomics Viewer (IGV) (https://www.broadinstitute.org/igv/ home)are some options for visualization of multidimensional genomic data, while Cytoscape provides excellent functionality in displaying relational networks from proteomic or genomic data. The UCSC Genome Browser, IGV, and Cytoscape each have an interactive user interface, whereas Circos graphs require altering the underlying data in text files to change the visualization. The UCSC Genome Browser, IGV, and Circos programs also generate static visualizations, and Circos can also output html files. Cytoscape allows a truly interactive visualization platform that can be dynamically manipulated by the user (Figure 2). The information contained in these multi-dimensional visualizations can be very complex and therefore elements such as size, shape, color depict important metrics. However, keep in mind publication guidelines when generating figures as some journals have specific rules on the color palettes allowed. In particular, some journals may request that authors refrain from using red and green in figures to help visualization by color-blind readers.

Next generation sequencing (NGS) and genotyping array-based projects generate exceptionally large amounts of data regarding human genome variability, regulatory elements, expression profiles, and epigenetic marks. Genome viewers are essential tools that allow the researcher to investigate the genomic context of their locus of interest, and are useful for generating hypotheses regarding the complex regulatory mechanisms affecting human disease. Programs such as Artemis (Rutherford et al. 2000), Savant (Fiume et al. 2010), and BamView (Carver et al. 2010) are good options to visualize NGS data sets. Additionally, tools such as the Integrative Genomics Viewer (IGV) and the UCSC Genome Browser are able to compile diverse data sets from NGS or array-based platforms for a comprehensive analysis of different types of data (Kent et al. 2002; Robinson et al. 2011; Thorvaldsdottir et al. 2013).

These genome viewers allow researchers to upload their own data alongside publically accessible data sets for comparative and integrative analyses. These platforms are very comprehensive and dynamic: users can focus on predefined features to specific regions of interest and view the locus at different scales (from nucleotide-level resolution to chromosome bands). Genome regions are richly annotated with data from several different projects including the ENCODE project (Djebali et al. 2012; Dunham et al. 2012; Gerstein et al. 2012; Neph et al. 2012; Sanyal et al. 2012; Thurman et al. 2012). ENCODE has cataloged a vast array of functional elements in the human genome and has deposited its data with the UCSC Genome Bioinformatics website (http://genome.ucsc.edu). Additionally, the UCSC Genome Browser can be used to create personalized private sessions to share data and results with collaborators or with students. We found this option to be ideal to share results among lab members working on the same project as well as within different laboratories in a consortium.

Viewing data is quite simple on the UCSC Genome Browser, but it lacks in automated data analysis functionality. Platforms such as Galaxy ((http://galaxyproject.org/)(Blankenberg et al. 2010; Giardine et al. 2005; Goecks et al. 2010), written in Python are a good place to 
start and can be used to establish workflows that include user inputs and data integration with data available on the UCSC Genome Browser, BioMart (http://www.biomart.org/), or InterMine (http://intermine.github.io/intermine.org/). This tool provides an interactive platform to aid in genome analysis.

Circos (http://circos.ca/) is a software tool developed by Martin Krzywinski at the Genome Sciences Centre in Vancouver, Canada (Krzywinski et al. 2009). 'Circos plot' as it is referred to in the literature is meant to be a visualization tool to represent complex data that would otherwise be depicted using lengthy spreadsheets and tables. It was originally designed to visualize genomic data such as mutation and structural variation in cancer genomes. For example, a common Circos plot, seen in many genomics articles is used to represent different somatic alterations found in cancer cells, including deletions, insertions, point mutations and translocations between two or more loci. Since Circos plots are of a circular orientation, they are ideal to represent multiple layers of information about a specific genomic locus in concentric circles known as 'tracks'. Circos is a Perl-based program but once all the modules have been installed and after practicing the main online tutorials, it does not require extensive Perl knowledge. For those with limited programming experience, Circos also offers an online tool where you can load your data in a table format and a plot is automatically generated. This online tool however, can be used only for a limited number of data points.

Depicting genomic structural variation was the main goal of Circos but it can be used to visualize many different data types and their relationships. Circos generates both png/svg files as well as html files. With additional tools such as Java programming or some basic knowledge of database management, advanced users can implement an interactive webpage to expand beyond the static images that Circos generates. However, due to the circular nature of the figures updates require re-mapping of the hyperlinks attached to each data point because the relative position of previously depicted data points change as well.

Cytoscape (www.cytoscape.org) provides an excellent platform for representing molecular and genetic interaction datasets (Shannon et al. 2003). This program is open source and allows the user to visualize simple and complex networks with associated attributes of both nodes and edges. Unlike the UCSC Genome Browser and Circos, Cytoscape also acts as a data integration and analysis tool through core applications. It can calculate network statistics, such as density, node degree distribution, shortest path length, as well as other variables that describe network topology. Additionally, the core tools can be used to integrate multiple datasets and adapt the visualization settings. A number of specialized downloadable "Apps" (Previously referred to as "Plug-ins") that can be run through the Cytoscape interface provides a robust analytical pipeline. Third party App developers have contributed numerous tools that aid in the analysis of biological networks. Many of these Apps can also be run from the command line or through the developer's website, but the integration with Cytoscape visualization tools can provide insightful abstract visualizations that depict features of the underlying data.

Cytoscape frequently provides updated releases of the program and is currently distributing version 3.x. A drawback of third party App development is that support for newer versions 
of Cytoscape may be lacking. As a temporary solution Apps can be run on older versions of Cytoscape (Saito et al. 2012). GeneMANIA (http://www.genemania.org/) is a Cytoscape App that can also be used as stand-alone web tool for the novice to explore datasets without the need to be proficient in Cytoscape.

\section{Dataset analysis}

A primary goal of systems-based projects that utilize large datasets is to generate biologically meaningful testable hypotheses from the underlying data. For the experimentalist, these large datasets are just the beginning. While systems biologists focus on the integration of data to develop unified theories of biological phenomena, they represent a subset of the research community as a whole where the primary focus has been reductionist in nature. Regardless of their focus, both groups need to use computational tools to aid in data analysis.

The types of analytical tools that can be used are dependent upon the available datasets chosen by the researcher. The preferred tools should be decided upon early in the planning stages of the project so that any biological data sets generated will be available to be integrated directly into the analysis pipeline. For instance, projects that will score proteinprotein interactions of affinity purification-mass spectrometry (AP-MS) need to have at least two replicate screens for each bait if the significance analysis of interactome (SAINT) algorithm is to be applied (Choi et al. 2011). Additionally, SAINT can use either an unsupervised mixture model where interactions are scored relative to other baits in the screen or a semi-supervised mixture model that factors in control screens. The unsupervised model would not work well with evolutionarily conserved proteins as baits because they may have the same protein partners or with baits that exist in the same complex or pathway. Therefore, it is important to understand the needed inputs and the biological context of the data prior to utilizing a data analysis platform.

Once the needed data is generated in the lab or extracted from public databases it can be run on a number of different computational resources or through a single workflow with different parameters of analysis. In general terms, most of these analyses will provide output regarding one or more of the following features: lists of altered genes/transcripts/proteins, network organization, annotation, overlapping features through data integration, and pathway modeling. Many times, the output from one analysis is fed into another tool to refine the knowledge base. One emerging issue is keeping track of all of the tools, workflows, and parameters used in a bioinformatics project. To ensure data integrity, reproducibility and optimization of workflow performance, data provenance models, such as BioQ (Saccone et al. 2012), SemPoD (Jayapandian et al. 2012), and PROV-DM model (de Paula et al. 2013), have been developed to track the origin of the biological data and the processes used to analyze it.

The goal of this review is not to assign computational tools to specific projects, but rather inspire the individual researcher to explore all of the options available to make full use of their data. To this end, it is helpful to consider several recently published studies that make 
use of computational tools and how the bioinformatics techniques were used to decipher the underlying biology of large datasets.

\section{Project Example 1: Protein interaction network modularity (Hauri et al. 2013)}

This project completed an elegant protein-protein interaction network analysis of human Hpo signaling pathway, which controls tissue and organ homeostasis in metazoans (Harvey and Tapon 2007; Pan 2007). In this study, the eight core proteins of the Hpo pathway and 26 secondary baits, which interacted with one of the core components, were analyzed by affinity purification coupled to mass spectrometry. To assign protein identifications from the experiments, this group used the bioinformatics pipeline X!Tandem tools (Craig and Beavis 2004) to search the spectra and the Trans Proteomic Pipeline (Deutsch et al. 2010) components PeptideProphet and ProteinProphet to statistically evaluate spectra matches and protein inference. Spectral counting using Abacus (Fermin et al. 2011) was used to determine the normalized spectral abundance factor, NSAF, which helped refine the dataset into a high confidence interacting proteins (HCIP) list consisting of 270 interactions from 480 total interactions. The data was then visualized using Cytoscape.

This and similar types of mass spectrometry data analysis pipelines have become routine for many researchers utilizing mass spectrometry, but this paper was able to take the analysis of protein interactions a step further using a cluster analysis of HCIP abundance in the mass spectrometry experiments relative to the bait. Using an un-centered Pearson correlation calculation, the authors were able to demonstrate the modularity of the Hpo pathway interactome. This added analysis resulted in the discovery that each of the three main modular pathways associated with Hpo signaling converged on the effector protein YAP1, which indicates that this protein is essential for coupling the biological processes of cell polarity and cell growth controlled by the Hpo pathway. This type of clustering analysis was previously shown to determine the modular nature of biological networks (Sardiu et al. 2008). This particular case study exemplifies the utility of a streamlined bioinformatics tool pipeline.

\section{Project Example 2: Multiple lines of evidence integration (Tamborero et al. 2013b)}

When determining the genes that are responsible for driving carcinogenesis it is important to understand the initiating events and the evolution of tumors, essential knowledge for the development of precision medicine. Several computational models have been developed to identify these cancer driver genes including MuSiC (Dees et al. 2012), OncodriveFM (Gonzalez-Perez and Lopez-Bigas 2012), OncodriveCLUST (Tamborero et al. 2013a), MutSig (Lawrence et al. 2013), and ActiveDriver (Reimand and Bader 2013). The authors of this particular study propose that classifying cancer driver genes is improved by using multiple evidence predictions. In essence, high-confidence cancer driver (HCD) genes can be classified as such if they are picked up as "hits" in more than one of the predictions methods described above. By taking a heuristic approach, the authors identify a list of 291 HCDs of which 165 are novel having no previous classification as a cancer genes in the Cancer Gene Census (Futreal et al. 2004). This particular study is an excellent example of multiple bioinformatics tools being designed for the same purpose. Although each tool has 
its own strengths and weaknesses, when combined their capacity to identify biologically significant events is enhanced.

\section{Project Example 3: Integrating diverse data sets for somatic mutation analysis (Reimand and Bader 2013)}

This example is an illustration of more advanced computational problems and the development of new models. While this strategy may be too complex for beginners it provides an excellent example of how computational programs in the lab can be used to drive discovery. This research involves an elegant demonstration of deciphering underlying biological phenomena from the integration of multiple existing data sets with the development of novel statistical analyses. In this study, the authors integrated data sets that included 10,900 missense somatic cancer mutations from 793 samples covering 8 cancer types along with any available clinical outcomes data (Ding et al. 2008; Jones et al. 2008; Parsons et al. 2008; Puente et al. 2011; TCGA 2008, 2011; Totoki et al. 2011; Wood et al. 2007), 73,872 phosphorylation events in 10,279 proteins (Dinkel et al. 2011; Hornbeck et al. 2012; Keshava Prasad et al. 2009), and an author compiled data set of 4,823 kinase-substrate interactions. The goal of this integration was to study the correlation between single nucleotide variants that affect phosphorylation (pSNVs) and downstream signaling events in cancer. This type of analysis is significant because pSNVs occur more frequently than expected, indicating the importance of these variants on cancer pathways.

To identify genes with significant pSNVs, this group developed a linear regression model named ActiveDriver, written in R, which found a total of 58 genes with significantly mutated phosphorylation sites. The researchers also developed another search algorithm named HyperModules that analyzes local network characteristics and assesses correlation to clinical outcomes. The analysis yielded 16 statistically significant signaling modules associated with cancer survival data. Additionally, a functional enrichment analyses based on gene ontology and pathway annotations of the pSNV genes were performed using GO categories (Ashburner et al. 2000), REACTOME pathways (Matthews et al. 2009), and the CORUM database of protein complexes (Ruepp et al. 2010). This revealed a number of pSNV enrichments in pathways, complexes, and biological processes associated with cancer. Highly integrative research programs such as this highlight the ability to utilize publicly available data sets to develop novel models to explain biological systems and generate new hypotheses.

\section{Final considerations}

The experience of the laboratory in incorporating computational resources and the case studies presented here illustrate how, with basic to intermediate programming capabilities, one can significantly streamline the data analysis for a project. Despite the potential of this approach several barriers to its implementation exist. Many times these are trivial issues such as file formats and conversions between operating systems. Despite the challenges we believe that when checking line endings in text files and compiling software become second nature to experimental biologists many valuable datasets can be manipulated to enrich a research program. 
Consistent use of bioinformatics tools and programming will lead to the inevitable bug that needs to be sorted out. As one gets more acquainted with programming and various syntaxes, debugging becomes much easier. It is also useful to know that the online community has probably already encountered and solved your issue, or one very similar to it, and quick web searches for solutions can save time. Websites like stackoverflow.com are an excellent repository for computer software and scripting issues; you can receive expert advice on overcoming your own programming problems by posting questions to the online community.

In the end there are two choices to personal advancement of programming knowledge: do it yourself, or take courses. It may take a long time as you fit it in with experiments, writing manuscripts, and applying for grants. On the other hand, taking an introductory course can provide you with a wealth of knowledge and allow you to apply it quickly. However, most introductory courses will focus on one programming language and operating system and you will likely need to learn much on your own based on the computing requirements of each analysis. Finally, introductory bioinformatics courses should be adopted as core curricula for biology majors at both the undergraduate and graduate levels. This will provide researchers with the basic knowledge needed to decipher biological meaning from omics level research.

Importantly, the transition to include computational tools to your cancer genetics program needs to be made not only on the personal 'mind-set' level but also implemented as a laboratory 'mind-set'. A simple and convenient approach is to choose a small set of tools, datasets, and programming languages. Once the choice is made different members of the laboratory can be assigned tasks: one person will become the reference for the Genome Browser, or TCGA or ENCODE datasets; one person will be responsible for learning Circos, etc. This way, lab members can act as springboards for other members that wish to apply these tools to their project. The matching of which tools to assign to which individual should follow their skills as well as how the resource is critical for that individual's project.

Although the road to a more computation-literate lab is a rocky one, we are certain that the simple recommendations and suggestions described here show the way to chart a path suited to each laboratory. It is our opinion that these efforts will pay by generating novel hypotheses and enriching the interpretation of your biological results.

\section{Acknowledgments}

Work in the Monteiro Lab is funded by NIH awards U19 CA148112 (GAME-ON consortium), U01 CA116167, R21 CA184996 (to N.W.) and by awards from the Moffitt Foundation.

\section{Abbreviations}

$\begin{array}{ll}\text { AP-MS } & \text { affinity purification coupled to mass spectrometry } \\ \text { ENCODE } & \text { Encyclopedia of DNA Elements } \\ \text { FANTOM } & \text { Functional Annotation of the Mammalian Genome } \\ \text { HCIP } & \text { high confidence interacting proteins }\end{array}$




$\begin{array}{ll}\text { ICGC } & \text { The International Cancer Genomics Consortium } \\ \text { MIAME } & \text { minimal information about microarray experiments } \\ \text { NSAF } & \text { normalized spectral abundance factor } \\ \text { pSNVs } & \text { Single Nucleotide Variants in phosphorylation sites } \\ \text { SAINT } & \text { significance analysis of interactome } \\ \text { TCGA } & \text { The Cancer Genome Atlas }\end{array}$

\section{References}

Ashburner M, Ball CA, Blake JA, Botstein D, Butler H, Cherry JM, Davis AP, Dolinski K, Dwight SS, Eppig JT, Harris MA, Hill DP, Issel-Tarver L, Kasarskis A, Lewis S, Matese JC, Richardson JE, Ringwald M, Rubin GM, Sherlock G. Gene ontology: tool for the unification of biology. The Gene Ontology Consortium. Nat Genet. 2000; 25:25-9.10.1038/75556 [PubMed: 10802651]

Benito M, Parker J, Du Q, Wu J, Xiang D, Perou CM, Marron JS. Adjustment of systematic microarray data biases. Bioinformatics. 2004; 20:105-14. [PubMed: 14693816]

Blankenberg D, Von Kuster G, Coraor N, Ananda G, Lazarus R, Mangan M, Nekrutenko A, Taylor J. Galaxy: a web-based genome analysis tool for experimentalists. Curr Protoc Mol Biol Chapter 19: Unit. 2010; 19(10):1-21.10.1002/0471142727.mb1910s89

Bojesen SE, Pooley KA, Johnatty SE, Beesley J, Michailidou K, Tyrer JP, Edwards SL, Pickett HA, Shen HC, Smart CE, Hillman KM, Mai PL, Lawrenson K, Stutz MD, Lu Y, Karevan R, Woods N, Johnston RL, French JD, Chen X, Weischer M, Nielsen SF, Maranian MJ, Ghoussaini M, Ahmed S, Baynes C, Bolla MK, Wang Q, Dennis J, McGuffog L, Barrowdale D, Lee A, Healey S, Lush M, Tessier DC, Vincent D, Bacot F, Vergote I, Lambrechts S, Despierre E, Risch HA, Gonzalez-Neira A, Rossing MA, Pita G, Doherty JA, Alvarez N, Larson MC, Fridley BL, Schoof N, Chang-Claude J, Cicek MS, Peto J, Kalli KR, Broeks A, Armasu SM, Schmidt MK, Braaf LM, Winterhoff B, Nevanlinna H, Konecny GE, Lambrechts D, Rogmann L, Guenel P, Teoman A, Milne RL, Garcia JJ, Cox A, Shridhar V, Burwinkel B, Marme F, Hein R, Sawyer EJ, Haiman CA, Wang-Gohrke S, Andrulis IL, Moysich KB, Hopper JL, Odunsi K, Lindblom A, Giles GG, Brenner H, Simard J, Lurie G, Fasching PA, Carney ME, Radice P, Wilkens LR, Swerdlow A, Goodman MT, Brauch H, Garcia-Closas M, Hillemanns P, Winqvist R, Durst M, Devilee P, Runnebaum I, Jakubowska A, Lubinski J, Mannermaa A, Butzow R, et al. Multiple independent variants at the TERT locus are associated with telomere length and risks of breast and ovarian cancer. Nat Genet. 2013; 45:371-84. 10.1038/ng.2566 ng.2566 [pii]. [PubMed: 23535731]

Carver T, Bohme U, Otto TD, Parkhill J, Berriman M. BamView: viewing mapped read alignment data in the context of the reference sequence. Bioinformatics. 2010; 26:676-7.10.1093/ bioinformatics/btq010 [PubMed: 20071372]

Chen C, Grennan K, Badner J, Zhang D, Gershon E, Jin L, Liu C. Removing batch effects in analysis of expression microarray data: an evaluation of six batch adjustment methods. PLoS One. 2011; 6:e17238.10.1371/journal.pone.0017238 [PubMed: 21386892]

Choi H, Larsen B, Lin ZY, Breitkreutz A, Mellacheruvu D, Fermin D, Qin ZS, Tyers M, Gingras AC, Nesvizhskii AI. SAINT: probabilistic scoring of affinity purification-mass spectrometry data. Nat Methods. 2011; 8:70-3.10.1038/nmeth.1541 [PubMed: 21131968]

Craig R, Beavis RC. TANDEM: matching proteins with tandem mass spectra. Bioinformatics. 2004; 20:1466-7.10.1093/bioinformatics/bth092 [PubMed: 14976030]

de Paula R, Holanda M, Gomes LS, Lifschitz S, Walter ME. Provenance in bioinformatics workflows. BMC Bioinformatics. 2013; 14(Suppl 11):S6.10.1186/1471-2105-14-S11-S6 [PubMed: 24564294]

Dees ND, Zhang Q, Kandoth C, Wendl MC, Schierding W, Koboldt DC, Mooney TB, Callaway MB, Dooling D, Mardis ER, Wilson RK, Ding L. MuSiC: identifying mutational significance in cancer genomes. Genome Res. 2012; 22:1589-98.10.1101/gr.134635.111 [PubMed: 22759861] 
DeRisi J, Penland L, Brown PO, Bittner ML, Meltzer PS, Ray M, Chen Y, Su YA, Trent JM. Use of a cDNA microarray to analyse gene expression patterns in human cancer. Nat Genet. 1996; 14:45760.10.1038/ng1296-457 [PubMed: 8944026]

Deutsch EW, Mendoza L, Shteynberg D, Farrah T, Lam H, Tasman N, Sun Z, Nilsson E, Pratt B, Prazen B, Eng JK, Martin DB, Nesvizhskii AI, Aebersold R. A guided tour of the Trans-Proteomic Pipeline. Proteomics. 2010; 10:1150-9.10.1002/pmic.200900375 [PubMed: 20101611]

Ding L, Getz G, Wheeler DA, Mardis ER, McLellan MD, Cibulskis K, Sougnez C, Greulich H, Muzny DM, Morgan MB, Fulton L, Fulton RS, Zhang Q, Wendl MC, Lawrence MS, Larson DE, Chen K, Dooling DJ, Sabo A, Hawes AC, Shen H, Jhangiani SN, Lewis LR, Hall O, Zhu Y, Mathew T, Ren Y, Yao J, Scherer SE, Clerc K, Metcalf GA, Ng B, Milosavljevic A, Gonzalez-Garay ML, Osborne JR, Meyer R, Shi X, Tang Y, Koboldt DC, Lin L, Abbott R, Miner TL, Pohl C, Fewell G, Haipek C, Schmidt H, Dunford-Shore BH, Kraja A, Crosby SD, Sawyer CS, Vickery T, Sander S, Robinson J, Winckler W, Baldwin J, Chirieac LR, Dutt A, Fennell T, Hanna M, Johnson BE, Onofrio RC, Thomas RK, Tonon G, Weir BA, Zhao X, Ziaugra L, Zody MC, Giordano T, Orringer MB, Roth JA, Spitz MR, Wistuba II, Ozenberger B, Good PJ, Chang AC, Beer DG, Watson MA, Ladanyi M, Broderick S, Yoshizawa A, Travis WD, Pao W, Province MA, Weinstock GM, Varmus HE, Gabriel SB, Lander ES, Gibbs RA, Meyerson M, Wilson RK. Somatic mutations affect key pathways in lung adenocarcinoma. Nature. 2008; 455:106975.10.1038/nature07423 [PubMed: 18948947]

Dinkel H, Chica C, Via A, Gould CM, Jensen LJ, Gibson TJ, Diella F. Phospho.ELM: a database of phosphorylation sites-update 2011. Nucleic Acids Res. 2011; 39:D261-7.10.1093/nar/gkq1104 [PubMed: 21062810]

Djebali S, Davis CA, Merkel A, Dobin A, Lassmann T, Mortazavi A, Tanzer A, Lagarde J, Lin W, Schlesinger F, Xue C, Marinov GK, Khatun J, Williams BA, Zaleski C, Rozowsky J, Roder M, Kokocinski F, Abdelhamid RF, Alioto T, Antoshechkin I, Baer MT, Bar NS, Batut P, Bell K, Bell I, Chakrabortty S, Chen X, Chrast J, Curado J, Derrien T, Drenkow J, Dumais E, Dumais J, Duttagupta R, Falconnet E, Fastuca M, Fejes-Toth K, Ferreira P, Foissac S, Fullwood MJ, Gao H, Gonzalez D, Gordon A, Gunawardena H, Howald C, Jha S, Johnson R, Kapranov P, King B, Kingswood C, Luo OJ, Park E, Persaud K, Preall JB, Ribeca P, Risk B, Robyr D, Sammeth M, Schaffer L, See LH, Shahab A, Skancke J, Suzuki AM, Takahashi H, Tilgner H, Trout D, Walters N, Wang H, Wrobel J, Yu Y, Ruan X, Hayashizaki Y, Harrow J, Gerstein M, Hubbard T, Reymond A, Antonarakis SE, Hannon G, Giddings MC, Ruan Y, Wold B, Carninci P, Guigo R, Gingeras TR. Landscape of transcription in human cells. Nature. 2012; 489:101-8. 10.1038/ nature11233 nature11233 [pii]. [PubMed: 22955620]

Dunham I, Kundaje A, Aldred SF, Collins PJ, Davis CA, Doyle F, Epstein CB, Frietze S, Harrow J, Kaul R, Khatun J, Lajoie BR, Landt SG, Lee BK, Pauli F, Rosenbloom KR, Sabo P, Safi A, Sanyal A, Shoresh N, Simon JM, Song L, Trinklein ND, Altshuler RC, Birney E, Brown JB, Cheng C, Djebali S, Dong X, Ernst J, Furey TS, Gerstein M, Giardine B, Greven M, Hardison RC, Harris RS, Herrero J, Hoffman MM, Iyer S, Kelllis M, Kheradpour P, Lassman T, Li Q, Lin X, Marinov GK, Merkel A, Mortazavi A, Parker SC, Reddy TE, Rozowsky J, Schlesinger F, Thurman RE, Wang J, Ward LD, Whitfield TW, Wilder SP, Wu W, Xi HS, Yip KY, Zhuang J, Bernstein BE, Green ED, Gunter C, Snyder M, Pazin MJ, Lowdon RF, Dillon LA, Adams LB, Kelly CJ, Zhang J, Wexler JR, Good PJ, Feingold EA, Crawford GE, Dekker J, Elinitski L, Farnham PJ, Giddings MC, Gingeras TR, Guigo R, Hubbard TJ, Kellis M, Kent WJ, Lieb JD, Margulies EH, Myers RM, Starnatoyannopoulos JA, Tennebaum SA, Weng Z, White KP, Wold B, Yu Y, Wrobel J, Risk BA, Gunawardena HP, Kuiper HC, Maier CW, Xie L, Chen X, Mikkelsen TS, et al. An integrated encyclopedia of DNA elements in the human genome. Nature. 2012; 489:57-74. 10.1038/nature11247 nature11247 [pii]. [PubMed: 22955616]

Fare TL, Coffey EM, Dai H, He YD, Kessler DA, Kilian KA, Koch JE, LeProust E, Marton MJ, Meyer MR, Stoughton RB, Tokiwa GY, Wang Y. Effects of atmospheric ozone on microarray data quality. Anal Chem. 2003; 75:4672-5. [PubMed: 14632079]

Fermin D, Basrur V, Yocum AK, Nesvizhskii AI. Abacus: a computational tool for extracting and preprocessing spectral count data for label-free quantitative proteomic analysis. Proteomics. 2011; 11:1340-5.10.1002/pmic.201000650 [PubMed: 21360675]

Fiume M, Williams V, Brook A, Brudno M. Savant: genome browser for high-throughput sequencing data. Bioinformatics. 2010; 26:1938-44.10.1093/bioinformatics/btq332 [PubMed: 20562449] 
Fourment M, Gillings MR. A comparison of common programming languages used in bioinformatics. BMC Bioinformatics. 2008; 9:82.10.1186/1471-2105-9-82 [PubMed: 18251993]

Futreal PA, Coin L, Marshall M, Down T, Hubbard T, Wooster R, Rahman N, Stratton MR. A census of human cancer genes. Nat Rev Cancer. 2004; 4:177-83.10.1038/nrc1299 [PubMed: 14993899]

Gerloff DL, Woods NT, Farago AA, Monteiro AN. BRCT domains: A little more than kin, and less than kind. FEBS Lett. 2012; 586:2711-6. doi: S0014-5793(12)00365-1 [pii] 10.1016/j.febslet. 2012.05.005. [PubMed: 22584059]

Gerstein MB, Kundaje A, Hariharan M, Landt SG, Yan KK, Cheng C, Mu XJ, Khurana E, Rozowsky J, Alexander R, Min R, Alves P, Abyzov A, Addleman N, Bhardwaj N, Boyle AP, Cayting P, Charos A, Chen DZ, Cheng Y, Clarke D, Eastman C, Euskirchen G, Frietze S, Fu Y, Gertz J, Grubert F, Harmanci A, Jain P, Kasowski M, Lacroute P, Leng J, Lian J, Monahan H, O'Geen H, Ouyang Z, Partridge EC, Patacsil D, Pauli F, Raha D, Ramirez L, Reddy TE, Reed B, Shi M, Slifer T, Wang J, Wu L, Yang X, Yip KY, Zilberman-Schapira G, Batzoglou S, Sidow A, Farnham PJ, Myers RM, Weissman SM, Snyder M. Architecture of the human regulatory network derived from ENCODE data. Nature. 2012; 489:91-100. doi: 10.1038/nature11245 nature11245 [pii]. [PubMed: 22955619]

Giardine B, Riemer C, Hardison RC, Burhans R, Elnitski L, Shah P, Zhang Y, Blankenberg D, Albert I, Taylor J, Miller W, Kent WJ, Nekrutenko A. Galaxy: a platform for interactive large-scale genome analysis. Genome Res. 2005; 15:1451-5.10.1101/gr.4086505 [PubMed: 16169926]

Goecks J, Nekrutenko A, Taylor J. Galaxy: a comprehensive approach for supporting accessible, reproducible, and transparent computational research in the life sciences. Genome Biol. 2010; 11:R86.10.1186/gb-2010-11-8-r86 [PubMed: 20738864]

Gonzalez-Perez A, Lopez-Bigas N. Functional impact bias reveals cancer drivers. Nucleic Acids Res. 2012; 40:e169.10.1093/nar/gks743 [PubMed: 22904074]

Haddock, SHD.; Dunn, CW. Practical computing for biologists. 1. Sinauer Associates; Sunderland, Mass: 2011.

Harvey K, Tapon N. The Salvador-Warts-Hippo pathway - an emerging tumour-suppressor network. Nat Rev Cancer. 2007; 7:182-91.10.1038/nrc2070 [PubMed: 17318211]

Hauri S, Wepf A, van Drogen A, Varjosalo M, Tapon N, Aebersold R, Gstaiger M. Interaction proteome of human Hippo signaling: modular control of the co-activator YAP1. Mol Syst Biol. 2013; 9:713.10.1002/msb.201304750 [PubMed: 24366813]

Hirschhorn JN, Daly MJ. Genome-wide association studies for common diseases and complex traits. Nat Rev Genet. 2005; 6:95-108.10.1038/nrg1521 [PubMed: 15716906]

Hornbeck PV, Kornhauser JM, Tkachev S, Zhang B, Skrzypek E, Murray B, Latham V, Sullivan M. PhosphoSitePlus: a comprehensive resource for investigating the structure and function of experimentally determined post-translational modifications in man and mouse. Nucleic Acids Res. 2012; 40:D261-70.10.1093/nar/gkr1122 [PubMed: 22135298]

Ioannidis JP, Allison DB, Ball CA, Coulibaly I, Cui X, Culhane AC, Falchi M, Furlanello C, Game L, Jurman G, Mangion J, Mehta T, Nitzberg M, Page GP, Petretto E, van Noort V. Repeatability of published microarray gene expression analyses. Nat Genet. 2009; 41:149-55.10.1038/ng.295 [PubMed: 19174838]

Iversen ES, Couch FJ, Goldgar DE, Tavtigian SV, Monteiro ANA. A Computational Method to Classify Variants of Uncertain Significance Using Functional Assay Data with Application to BRCA1. Cancer Epidemiology Biomarkers \& Prevention. 2011; 20:10781088.10.1158/1055-9965.epi-10-1214

Jayapandian CP, Zhao M, Ewing RM, Zhang GQ, Sahoo SS. A semantic proteomics dashboard (SemPoD) for data management in translational research. BMC Syst Biol. 2012; 6(Suppl 3):S20.10.1186/1752-0509-6-S3-S20 [PubMed: 23282161]

Johnson WE, Li C, Rabinovic A. Adjusting batch effects in microarray expression data using empirical Bayes methods. Biostatistics. 2007; 8:118-27.10.1093/biostatistics/kxj037 [PubMed: 16632515]

Jones S, Zhang X, Parsons DW, Lin JC, Leary RJ, Angenendt P, Mankoo P, Carter H, Kamiyama H, Jimeno A, Hong SM, Fu B, Lin MT, Calhoun ES, Kamiyama M, Walter K, Nikolskaya T, Nikolsky Y, Hartigan J, Smith DR, Hidalgo M, Leach SD, Klein AP, Jaffee EM, Goggins M, Maitra A, Iacobuzio-Donahue C, Eshleman JR, Kern SE, Hruban RH, Karchin R, Papadopoulos 
N, Parmigiani G, Vogelstein B, Velculescu VE, Kinzler KW. Core signaling pathways in human pancreatic cancers revealed by global genomic analyses. Science. 2008; 321:1801-1806. [PubMed: 18772397]

Judson, HF. The eighth day of creation: makers of the revolution in biology. Cold Spring Harbor Press; Cold Spring Harbor: 1996.

Karchin R, Monteiro AN, Tavtigian SV, Carvalho MA, Sali A. Functional Impact of Missense Variants in BRCA1 Predicted by Supervised Learning. PLoS Comput Biol. 2007; 3:e26. [PubMed: 17305420]

Kent WJ, Sugnet CW, Furey TS, Roskin KM, Pringle TH, Zahler AM, Haussler D. The human genome browser at UCSC. Genome Res. 2002; 12:996-1006. Article published online before print in May 2002. 10.1101/gr.229102 [PubMed: 12045153]

Keshava Prasad TS, Goel R, Kandasamy K, Keerthikumar S, Kumar S, Mathivanan S, Telikicherla D, Raju R, Shafreen B, Venugopal A, Balakrishnan L, Marimuthu A, Banerjee S, Somanathan DS, Sebastian A, Rani S, Ray S, Harrys Kishore CJ, Kanth S, Ahmed M, Kashyap MK, Mohmood R, Ramachandra YL, Krishna V, Rahiman BA, Mohan S, Ranganathan P, Ramabadran S, Chaerkady R, Pandey A. Human Protein Reference Database-2009 update. Nucleic Acids Res. 2009; 37:D767-72. doi: gkn892 [pii] 10.1093/nar/gkn892. [PubMed: 18988627]

Krzywinski M, Schein J, Birol I, Connors J, Gascoyne R, Horsman D, Jones SJ, Marra MA. Circos: an information aesthetic for comparative genomics. Genome Res. 2009; 19:1639-45. doi: gr. 092759.109 [pii] 10.1101/gr.092759.109. [PubMed: 19541911]

Lander ES. Array of hope. Nat Genet. 1999; 21:3-4.10.1038/4427 [PubMed: 9915492]

Lawrence MS, Stojanov P, Polak P, Kryukov GV, Cibulskis K, Sivachenko A, Carter SL, Stewart C, Mermel CH, Roberts SA, Kiezun A, Hammerman PS, McKenna A, Drier Y, Zou L, Ramos AH, Pugh TJ, Stransky N, Helman E, Kim J, Sougnez C, Ambrogio L, Nickerson E, Shefler E, Cortes ML, Auclair D, Saksena G, Voet D, Noble M, DiCara D, Lin P, Lichtenstein L, Heiman DI, Fennell T, Imielinski M, Hernandez B, Hodis E, Baca S, Dulak AM, Lohr J, Landau DA, Wu CJ, Melendez-Zajgla J, Hidalgo-Miranda A, Koren A, McCarroll SA, Mora J, Lee RS, Crompton B, Onofrio R, Parkin M, Winckler W, Ardlie K, Gabriel SB, Roberts CW, Biegel JA, Stegmaier K, Bass AJ, Garraway LA, Meyerson M, Golub TR, Gordenin DA, Sunyaev S, Lander ES, Getz G. Mutational heterogeneity in cancer and the search for new cancer-associated genes. Nature. 2013; 499:214-8.10.1038/nature12213 [PubMed: 23770567]

Lee MS, Green R, Marsillac SM, Coquelle N, Williams RS, Yeung T, Foo D, Hau DD, Hui B, Monteiro AN, Glover JN. Comprehensive analysis of missense variations in the BRCT domain of BRCA1 by structural and functional assays. Cancer Res. 2010; 70:4880-90. doi: 0008-5472.CAN-09-4563 [pii] 10.1158/0008-5472.CAN-09-4563. [PubMed: 20516115]

Matthews L, Gopinath G, Gillespie M, Caudy M, Croft D, de Bono B, Garapati P, Hemish J, Hermjakob H, Jassal B, Kanapin A, Lewis S, Mahajan S, May B, Schmidt E, Vastrik I, Wu G, Birney E, Stein L, D'Eustachio P. Reactome knowledgebase of human biological pathways and processes. Nucleic Acids Res. 2009; 37:D619-22.10.1093/nar/gkn863 [PubMed: 18981052]

Metzker ML. Sequencing technologies - the next generation. Nat Rev Genet. 2010; 11:31-46. doi: nrg2626 [pii] 10.1038/nrg2626. [PubMed: 19997069]

Mirkovic N, Marti-Renom MA, Weber BL, Sali A, Monteiro AN. Structure-based assessment of missense mutations in human BRCA1: implications for breast and ovarian cancer predisposition. Cancer Research. 2004; 64:3790-3797. [PubMed: 15172985]

Monteiro AN, Freedman ML. Lessons from postgenome-wide association studies: functional analysis of cancer predisposition loci. J Intern Med. 2013; 274:414-24.10.1111/joim.12085 [PubMed: 24127939]

Neph S, Vierstra J, Stergachis AB, Reynolds AP, Haugen E, Vernot B, Thurman RE, John S, Sandstrom R, Johnson AK, Maurano MT, Humbert R, Rynes E, Wang H, Vong S, Lee K, Bates D, Diegel M, Roach V, Dunn D, Neri J, Schafer A, Hansen RS, Kutyavin T, Giste E, Weaver M, Canfield T, Sabo P, Zhang M, Balasundaram G, Byron R, MacCoss MJ, Akey JM, Bender MA, Groudine M, Kaul R, Stamatoyannopoulos JA. An expansive human regulatory lexicon encoded in transcription factor footprints. Nature. 2012; 489:83-90. doi: 10.1038/nature11212 nature11212 [pii]. [PubMed: 22955618] 
Osborne JM, Bernabeu MO, Bruna M, Calderhead B, Cooper J, Dalchau N, Dunn SJ, Fletcher AG, Freeman R, Groen D, Knapp B, McInerny GJ, Mirams GR, Pitt-Francis J, Sengupta B, Wright DW, Yates CA, Gavaghan DJ, Emmott S, Deane C. Ten simple rules for effective computational research. PLoS Comput Biol. 2014; 10:e1003506.10.1371/journal.pcbi.1003506 [PubMed: 24675742]

Pan D. Hippo signaling in organ size control. Genes Dev. 2007; 21:886-97.10.1101/gad.1536007 [PubMed: 17437995]

Parsons DW, Jones S, Zhang X, Lin JC, Leary RJ, Angenendt P, Mankoo P, Carter H, Siu IM, Gallia GL, Olivi A, McLendon R, Rasheed BA, Keir S, Nikolskaya T, Nikolsky Y, Busam DA, Tekleab H, Diaz LA Jr, Hartigan J, Smith DR, Strausberg RL, Marie SK, Shinjo SM, Yan H, Riggins GJ, Bigner DD, Karchin R, Papadopoulos N, Parmigiani G, Vogelstein B, Velculescu VE, Kinzler KW. An integrated genomic analysis of human glioblastoma multiforme. Science. 2008; 321:1807-1812. [PubMed: 18772396]

Pharoah PD, Tsai YY, Ramus SJ, Phelan CM, Goode EL, Lawrenson K, Buckley M, Fridley BL, Tyrer JP, Shen H, Weber R, Karevan R, Larson MC, Song H, Tessier DC, Bacot F, Vincent D, Cunningham JM, Dennis J, Dicks E, Aben KK, Anton-Culver H, Antonenkova N, Armasu SM, Baglietto L, Bandera EV, Beckmann MW, Birrer MJ, Bloom G, Bogdanova N, Brenton JD, Brinton LA, Brooks-Wilson A, Brown R, Butzow R, Campbell I, Carney ME, Carvalho RS, Chang-Claude J, Chen YA, Chen Z, Chow WH, Cicek MS, Coetzee G, Cook LS, Cramer DW, Cybulski C, Dansonka-Mieszkowska A, Despierre E, Doherty JA, Dork T, du Bois A, Durst M, Eccles D, Edwards R, Ekici AB, Fasching PA, Fenstermacher D, Flanagan J, Gao YT, GarciaClosas M, Gentry-Maharaj A, Giles G, Gjyshi A, Gore M, Gronwald J, Guo Q, Halle MK, Harter P, Hein A, Heitz F, Hillemanns P, Hoatlin M, Hogdall E, Hogdall CK, Hosono S, Jakubowska A, Jensen A, Kalli KR, Karlan BY, Kelemen LE, Kiemeney LA, Kjaer SK, Konecny GE, Krakstad C, Kupryjanczyk J, Lambrechts D, Lambrechts S, Le ND, Lee N, Lee J, Leminen A, Lim BK, Lissowska J, Lubinski J, Lundvall L, Lurie G, Massuger LF, Matsuo K, McGuire V, et al. GWAS meta-analysis and replication identifies three new susceptibility loci for ovarian cancer. Nat Genet. 2013; 45:362-70. doi: 10.1038/ng.2564 ng.2564 [pii]. [PubMed: 23535730]

Puente XS, Pinyol M, Quesada V, Conde L, Ordonez GR, Villamor N, Escaramis G, Jares P, Bea S, Gonzalez-Diaz M, Bassaganyas L, Baumann T, Juan M, Lopez-Guerra M, Colomer D, Tubio JM, Lopez C, Navarro A, Tornador C, Aymerich M, Rozman M, Hernandez JM, Puente DA, Freije JM, Velasco G, Gutierrez-Fernandez A, Costa D, Carrio A, Guijarro S, Enjuanes A, Hernandez L, Yague J, Nicolas P, Romeo-Casabona CM, Himmelbauer H, Castillo E, Dohm JC, de Sanjose S, Piris MA, de Alava E, San Miguel J, Royo R, Gelpi JL, Torrents D, Orozco M, Pisano DG, Valencia A, Guigo R, Bayes M, Heath S, Gut M, Klatt P, Marshall J, Raine K, Stebbings LA, Futreal PA, Stratton MR, Campbell PJ, Gut I, Lopez-Guillermo A, Estivill X, Montserrat E, Lopez-Otin C, Campo E. Whole-genome sequencing identifies recurrent mutations in chronic lymphocytic leukaemia. Nature. 2011; 475:101-5. doi: 10.1038/nature10113 nature10113 [pii]. [PubMed: 21642962]

Reimand J, Bader GD. Systematic analysis of somatic mutations in phosphorylation signaling predicts novel cancer drivers. Mol Syst Biol. 2013; 9:637.10.1038/msb.2012.68 [PubMed: 23340843]

Robinson JT, Thorvaldsdottir H, Winckler W, Guttman M, Lander ES, Getz G, Mesirov JP. Integrative genomics viewer. Nat Biotechnol. 2011; 29:24-6.10.1038/nbt.1754 [PubMed: 21221095]

Ronaghi M. Pyrosequencing sheds light on DNA sequencing. Genome Res. 2001; 11:3-11. [PubMed: 11156611]

Ruepp A, Waegele B, Lechner M, Brauner B, Dunger-Kaltenbach I, Fobo G, Frishman G, Montrone C, Mewes HW. CORUM: the comprehensive resource of mammalian protein complexes-2009. Nucleic Acids Res. 2010; 38:D497-501.10.1093/nar/gkp914 [PubMed: 19884131]

Rutherford K, Parkhill J, Crook J, Horsnell T, Rice P, Rajandream MA, Barrell B. Artemis: sequence visualization and annotation. Bioinformatics. 2000; 16:944-5. [PubMed: 11120685]

Saccone SF, Quan J, Jones PL. BioQ: tracing experimental origins in public genomic databases using a novel data provenance model. Bioinformatics. 2012; 28:1189-91.10.1093/bioinformatics/bts117 [PubMed: 22426342] 
Saito R, Smoot ME, Ono K, Ruscheinski J, Wang PL, Lotia S, Pico AR, Bader GD, Ideker T. A travel guide to Cytoscape plugins. Nat Methods. 2012; 9:1069-76.10.1038/nmeth.2212 [PubMed: 23132118]

Sanyal A, Lajoie BR, Jain G, Dekker J. The long-range interaction landscape of gene promoters. Nature. 2012; 489:109-13. doi: 10.1038/nature11279 nature11279 [pii]. [PubMed: 22955621]

Sardiu ME, Cai Y, Jin J, Swanson SK, Conaway RC, Conaway JW, Florens L, Washburn MP. Probabilistic assembly of human protein interaction networks from label-free quantitative proteomics. Proc Natl Acad Sci U S A. 2008; 105:1454-9.10.1073/pnas.0706983105 [PubMed: 18218781]

Schena M, Shalon D, Davis RW, Brown PO. Quantitative monitoring of gene expression patterns with a complementary DNA microarray. Science. 1995; 270:467-70. [PubMed: 7569999]

Shannon P, Markiel A, Ozier O, Baliga NS, Wang JT, Ramage D, Amin N, Schwikowski B, Ideker T. Cytoscape: a software environment for integrated models of biomolecular interaction networks. Genome Res. 2003; 13:2498-504. doi: 10.1101/gr.1239303 13/11/2498 [pii]. [PubMed: 14597658]

Stajich JE, Block D, Boulez K, Brenner SE, Chervitz SA, Dagdigian C, Fuellen G, Gilbert JG, Korf I, Lapp H, Lehvaslaiho H, Matsalla C, Mungall CJ, Osborne BI, Pocock MR, Schattner P, Senger M, Stein LD, Stupka E, Wilkinson MD, Birney E. The Bioperl toolkit: Perl modules for the life sciences. Genome Res. 2002; 12:1611-8.10.1101/gr.361602 [PubMed: 12368254]

Tamborero D, Gonzalez-Perez A, Lopez-Bigas N. OncodriveCLUST: exploiting the positional clustering of somatic mutations to identify cancer genes. Bioinformatics. 2013a; 29:223844.10.1093/bioinformatics/btt395 [PubMed: 23884480]

Tamborero D, Gonzalez-Perez A, Perez-Llamas C, Deu-Pons J, Kandoth C, Reimand J, Lawrence MS, Getz G, Bader GD, Ding L, Lopez-Bigas N. Comprehensive identification of mutational cancer driver genes across 12 tumor types. Sci Rep. 2013b; 3:2650.10.1038/srep02650 [PubMed: 24084849]

TCGA. Comprehensive genomic characterization defines human glioblastoma genes and core pathways. Nature. 2008; 455:1061-8.10.1038/nature07385 [PubMed: 18772890]

TCGA. Integrated genomic analyses of ovarian carcinoma. Nature. 2011; 474:609-15.10.1038/ nature10166 [PubMed: 21720365]

Thorvaldsdottir H, Robinson JT, Mesirov JP. Integrative Genomics Viewer (IGV): high-performance genomics data visualization and exploration. Brief Bioinform. 2013; 14:178-92.10.1093/bib/ bbs017 [PubMed: 22517427]

Thurman RE, Rynes E, Humbert R, Vierstra J, Maurano MT, Haugen E, Sheffield NC, Stergachis AB, Wang H, Vernot B, Garg K, John S, Sandstrom R, Bates D, Boatman L, Canfield TK, Diegel M, Dunn D, Ebersol AK, Frum T, Giste E, Johnson AK, Johnson EM, Kutyavin T, Lajoie B, Lee BK, Lee K, London D, Lotakis D, Neph S, Neri F, Nguyen ED, Qu H, Reynolds AP, Roach V, Safi A, Sanchez ME, Sanyal A, Shafer A, Simon JM, Song L, Vong S, Weaver M, Yan Y, Zhang Z, Lenhard B, Tewari M, Dorschner MO, Hansen RS, Navas PA, Stamatoyannopoulos G, Iyer VR, Lieb JD, Sunyaev SR, Akey JM, Sabo PJ, Kaul R, Furey TS, Dekker J, Crawford GE, Stamatoyannopoulos JA. The accessible chromatin landscape of the human genome. Nature. 2012; 489:75-82. doi: 10.1038/nature11232 nature11232 [pii]. [PubMed: 22955617]

Totoki Y, Tatsuno K, Yamamoto S, Arai Y, Hosoda F, Ishikawa S, Tsutsumi S, Sonoda K, Totsuka H, Shirakihara T, Sakamoto H, Wang L, Ojima H, Shimada K, Kosuge T, Okusaka T, Kato K, Kusuda J, Yoshida T, Aburatani H, Shibata T. High-resolution characterization of a hepatocellular carcinoma genome. Nat Genet. 2011; 43:464-9. doi: ng.804 [pii] 10.1038/ng.804. [PubMed: 21499249]

Tufte, ER. Visual explanations : images and quantities, evidence and narrative. Graphics Press; Cheshire, Conn: 1997.

Tufte, ER. The visual display of quantitative information. 2. Graphics Press; Cheshire, Conn: 2001.

Weinberg RA. Coming full circle-from endless complexity to simplicity and back again. Cell. 2014; 157:267-71.10.1016/j.cell.2014.03.004 [PubMed: 24679541]

Wood LD, Parsons DW, Jones S, Lin J, Sjoblom T, Leary RJ, Shen D, Boca SM, Barber T, Ptak J, Silliman N, Szabo S, Dezso Z, Ustyanksky V, Nikolskaya T, Nikolsky Y, Karchin R, Wilson PA, 
Kaminker JS, Zhang Z, Croshaw R, Willis J, Dawson D, Shipitsin M, Willson JK, Sukumar S, Polyak K, Park BH, Pethiyagoda CL, Pant PV, Ballinger DG, Sparks AB, Hartigan J, Smith DR, Suh E, Papadopoulos N, Buckhaults P, Markowitz SD, Parmigiani G, Kinzler KW, Velculescu VE, Vogelstein B. The genomic landscapes of human breast and colorectal cancers. Science. 2007; 318:1108-13.10.1126/science.1145720 [PubMed: 17932254]

Woods NT, Mesquita RD, Sweet M, Carvalho MA, Li X, Liu Y, Nguyen H, Thomas CE, Iversen ES Jr, Marsillac S, Karchin R, Koomen J, Monteiro AN. Charting the landscape of tandem BRCT domain-mediated protein interactions. Sci Signal. 2012; 5:rs6. doi: 5/242/rs6 [pii]10.1126/ scisignal.2002255. [PubMed: 22990118] 


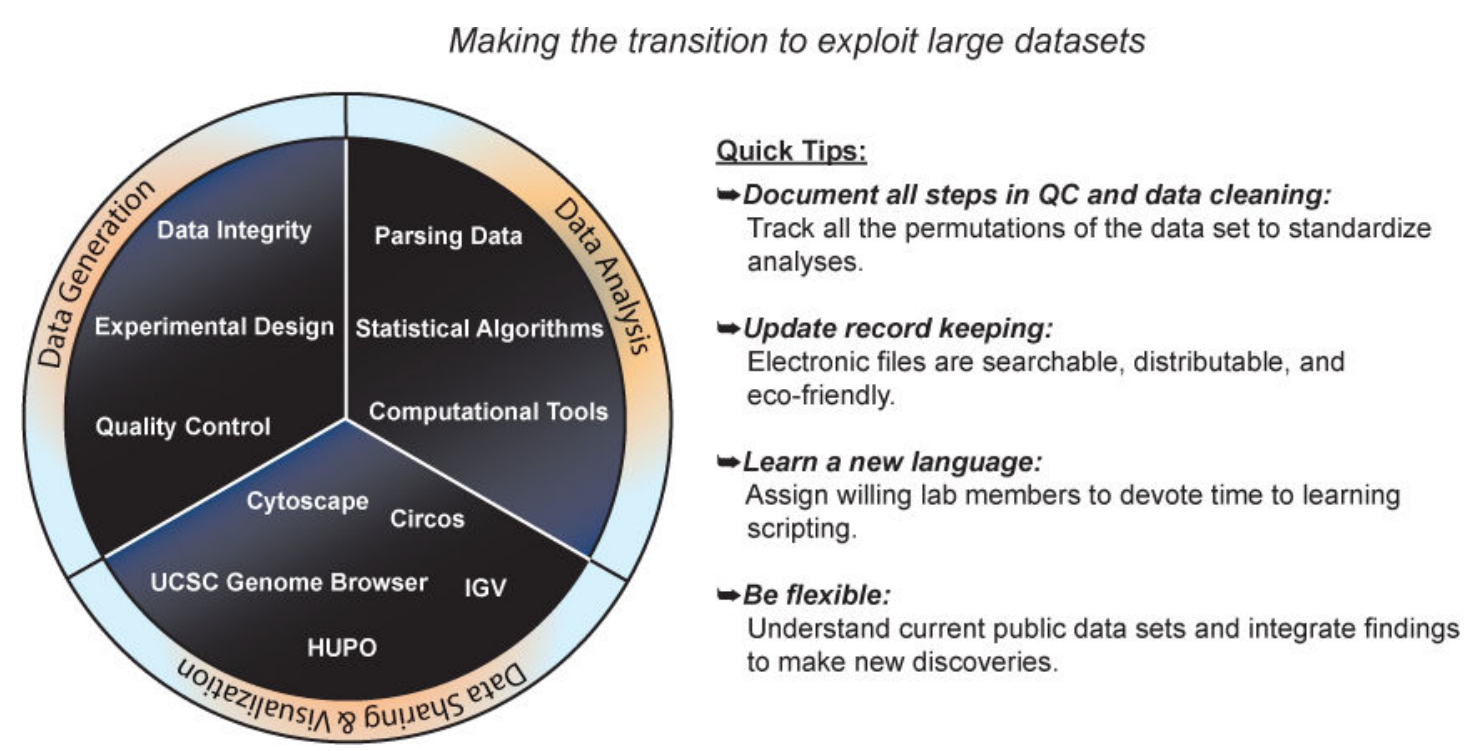

Figure 1. Making the transition to exploit large datasets A small set of recommendations to help in the laboratory transition to use computational resources. 


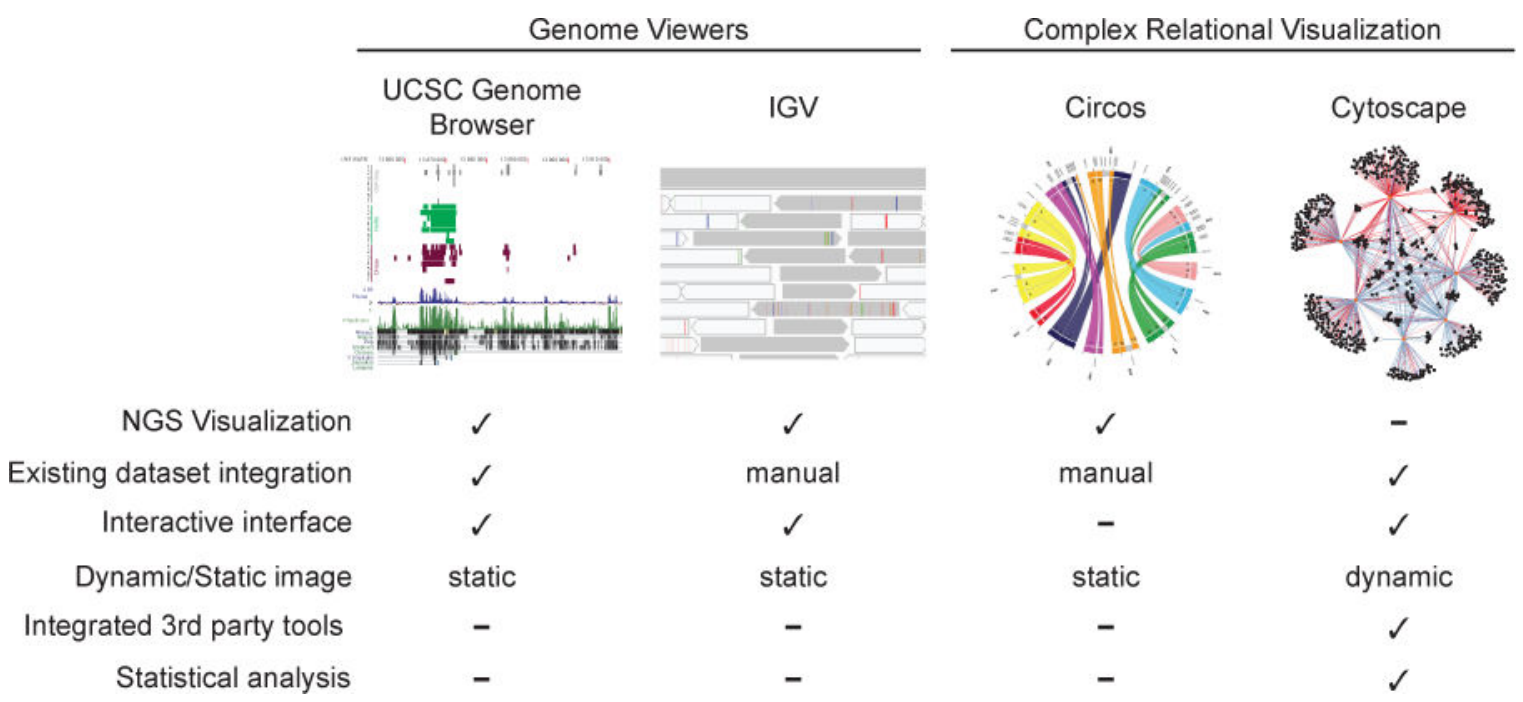

Figure 2. Visualization tools

A comparison of several widely used visualization tools for organizing and depicting largescale data sets. 


\section{Table 1}

\section{Data standards}

A list of groups that have established standardized formats for organizing and reporting different types of data.

\begin{tabular}{|c|c|c|c|}
\hline Group & Data type & Format(s) & Controlled Vocabularies \\
\hline $\begin{array}{l}\text { HUPO Proteomics Standards } \\
\text { Initiative (www.psidev.info) }\end{array}$ & $\begin{array}{c}\text { Mass Spectrometry Protein Identification } \\
\text { Mass Spectrometry Quantification } \\
\text { Protein Separations Molecular } \\
\text { Interactions }\end{array}$ & $\begin{array}{l}\text { mzML, TraML, mzData } \\
\text { mzldentML mzQuantML } \\
\text { GeIML, spML PSI-MI XML, } \\
\text { PSI-MITAB, PSI-PAR }\end{array}$ & $\begin{array}{c}\text { PSI-MS } \\
\text { sepCV PSI-MI CV, PAR } \\
\text { CV }\end{array}$ \\
\hline $\begin{array}{l}\text { The Functional Genomics Data } \\
\text { Society (www.fged.org) }\end{array}$ & $\begin{array}{c}\text { Microarray } \\
\text { High-throughput nucleotide sequencing }\end{array}$ & $\begin{array}{l}\text { MAGE-TAB, MAGE-ML } \\
\text { MINSEQE }\end{array}$ & $\begin{array}{l}\text { Ontology for Biomedical } \\
\text { Investigations (OBI) }\end{array}$ \\
\hline $\begin{array}{c}\text { Minimum Information for QTLs } \\
\text { and Association Studies (http:// } \\
\text { miqas.sourceforge.net/) }\end{array}$ & QTL and Association Studies & MIQAS-TAB, MIQAS-XML & \\
\hline $\begin{array}{l}\text { The Open Microscopy } \\
\text { Environment } \\
\text { (www.openmicroscopy.org) }\end{array}$ & Microscopy images & OME-TIFF & \\
\hline $\begin{array}{l}\text { Gene Ontology Consortium } \\
\text { (www.geneontology.org) }\end{array}$ & Gene/Protein Annotation & GAF2.0 & GO \\
\hline $\begin{array}{l}\text { Biological Pathways Exchange } \\
\text { - BioPAX (www.biopax.org) }\end{array}$ & Biological Pathways & RDF/XML & \\
\hline $\begin{array}{l}\text { Systems Biology Markup } \\
\text { Language (www.sbml.org) }\end{array}$ & Models of biological processes & XML & \\
\hline $\begin{array}{l}\text { Health Level Seven } \\
\text { International }\end{array}$ & Electronic health information & HL7 & Arden Syntax \\
\hline $\begin{array}{l}\text { Genome Atlas Toolkit (http:// } \\
\text { www.broadinstitute.org/gatk) }\end{array}$ & SNP Caller (UnifiedGenotyper) & $\mathrm{VCF}$ & \\
\hline
\end{tabular}

